\title{
The prognostic role of gender, age and physiology index and C-reactive protein/albumin ratio in idiopathic pulmonary fibrosis
}

\author{
İdiyopatik pulmoner fibroziste cinsiyet, yaş, fizyoloji indeksi ve C-reaktif \\ protein/albumin oranımın prognostik rolü
}

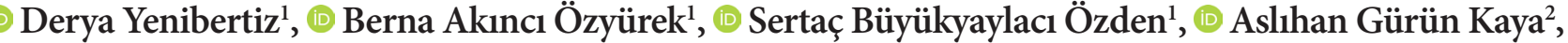 \\ (1) Yurdanur Erdoğan ${ }^{1}$ \\ ${ }^{1}$ University of Health Sciences, Ankara Atatürk Chest Diseases and Chest Surgery Training and Research Hospital, Department of Chest \\ Disease, Ankara, Turkey \\ ${ }^{2}$ Ankara University, School of Medicine, Department of Chest Diseases, Ankara, Turkey
}

Cite this article as / Bu makaleye atıf için: Yenibertiz D, Akıncı Özyürek B, Büyükyaylacı Özden S, Gürün Kaya A, Erdoğan Y. The prognostic role of gender, age and physiology index and C-reactive protein/albumin ratio in idiopathic pulmonary fibrosis. J Health Sci Med 2020; 3(3): 317-323.

\begin{abstract}
Aim: We aimed to compare the gender, age, and physiology index and C-reactive protein/albumin ratio in order to evaluate the prognosis, clinical course and survival of patients with idiopathic pulmonary fibrosis.

Material and Method: Forty-seven patients with idiopathic pulmonary fibrosis diagnosed by radiologically or pathologically in the 8th clinic of our hospital between January 2013 and December 2018 included to the study. Demographic characteristics, pulmonary function tests, 6-minute walk test values, echocardiography results, life span, additional diseases, treatment information, laboratory results of patients, gender, age and physiology indexes and initial C-reactive protein/albumin ratio of the patients were recorded from the patient files.

Results: According to gender, age and physiology index there were 25 (53.2\%) patients in stage I, 11 (23.4\%) patients in stage II, and 11 (23.4\%) patients in stage III. The patients were divided into 2 groups according to their life conditions. The rate of respiratory failure, the mean pulmonary arterial pressure and gender, age, and physiology stage were significantly higher (p grup 0.05) in the exitus group. The 6minute walk test was significantly lower in the exitus group $(\mathrm{p}<0.05)$. C-reactive protein/albumin ratio results were similar in both groups and there were no significant differences according to other parameters in both groups too. There was no significant difference between the C-reactive protein/albumin ratio values of the patients in each of the three gender, age, and physiology stages.

Conclusion: Gender, age, and physiology stage is easy and useful but C-reactive protein/albumin ratio isn't convenient to predict the prognosis of idiopathic pulmonary fibrosis. The elevation of pulmonary arterial pressure, low 6 minute walk test and presence of respiratory failure are poor prognostic factors in idiopathic pulmonary fibrosis.
\end{abstract}

Keywords: Idiopathic pulmonary fibrosis, IPF, GAP stage, CRP/Albumin ratio (CAR)

\section{ÖZ}

Amaç: Bu çalışmada idiopatik pulmoner fibrosisli hastaların prognozu, klinik seyri ve sağkalımını değerlendirmek için cinsiyet, yaş ve fizyoloji indeksi ve C-reaktif protein/albümin oranını karşılaştırmayı amaçladık.

Gereç ve Yöntem: Ocak 2013- Aralık 2018 tarihleri arasında hastanemizin 8. kliniğinde radyolojik veya patolojik olarak tanı konulmuş olan 47 idiopatik pulmoner fibrosis hastası çalışmaya dahil edildi. Hastaların demografik özellikleri, solunum fonksiyon testleri, 6 dakika yürüme testi değerleri, Ekokardiyografi sonuçları, yaşam süreleri, ek hastalıkları, tedavi bilgileri, laboratuvar sonuçları, cinsiyet, yaş ve fizyoloji indeksleri ve başlangıç C-reaktif protein/albümin oranları hasta dosyalarından kaydedildi.

Bulgular: Cinsiyet, yaş ve fizyoloji indeksine göre evre I'de $25(\% 53,2)$ hasta, evre II'de $11(\% 23,4)$ hasta ve evre III'te $11(\% 23,4)$ hasta vardı. Hastalar yaşam durumlarına göre 2 gruba ayrıldı. Eksitus olan grupta solunum yetmezliği, ortalama pulmoner arter basıncı ve cinsiyet, yaş ve fizyoloji evresi anlamlı olarak yüksekti $(\mathrm{p}<0,05) .6$ dakikalık yürüme testi eksitus grubunda anlamlı olarak düşüktü $(\mathrm{p}<0,05)$. C-reaktif protein/albümin oranı sonuçları her iki grupta benzerdi ve her iki grupta da diğer parametreler açısından anlamlı farklılık yoktu.

Sonuç: Cinsiyet, yaș ve fizyoloji evresi kolay ve kullanıșlıdır, ancak C-reaktif protein/albümin oranı idiopatik pulmoner fibrosisin prognozunu tahmin etmek için uygun değildir. Pulmoner arter basıncının yüksekliği, düşük 6 dakikalık yürüme testi sonuçları ve solunum yetmezliğinin varlığı idiopatik pulmoner fibrosisde kötü prognostik faktörlerdir.

Anahtar Kelimeler: İdiopatik pulmoner fibrosis, İPF, GAP indeksi, CAR 


\section{INTRODUCTION}

Idiopathic pulmonary fibrosis (IPF) is a progressive, non-curative and fibrosing lung disease with an average survival of 3-5 years from the time of diagnosis. It is characterized with unknown etiology and mostly seen in elder patients beyond 60 years of age (1). The prevalence of the disease has been estimated at 2-29 per 100,000 persons and its incidence is about 3-9 per 100,000 persons per year $(2,3)$. Mortality rates also appear to be rising, although this may partly reflect increased recognition and diagnosis (4-6).

In 2012, Ley et al. (7) described the gender, age and physiology (GAP) index and staging system, which can easily be used to estimate mortality in IPF patients. The GAP index includes gender, age, and two lung physiologic variables (forced vital capacity [FVC] and carbon monoxide diffusing capacity [DLCO]). GAP index is a scoring method used to determine prognosis, treatment plan and transplantation time in patients with IPF (8).

The C-reactive protein/albumin ratio (CAR) has been recently identified as a prognostic factor in various cancers. It has also been validated as a poor prognostic factor in pancreatic cancer, nasopharyngeal cancer, colorectal cancer and esophageal cancer etc (9-12). It has been revealed in a study that the CAR is an independent predictor for disease progression and death in patients with operable non small lung cancer (NSCLC) and in patients with small cell carcinoma (13-15). CAR might be used as a simple, inexpensive, and independent prognostic factor for overall survival of patients with advanced lung adenocarcinomas receiving platinum chemotherapy (16). CAR could not only reflect the individual's systematic inflammatory response but also perform as an indicator of nutritional status (17). However, no studies have explored the association between CAR and the clinical outcome of patients with IPF.

In this retrospective study, we aimed to compare the GAP index and CAR in order to evaluate the prognosis, clinical course and survival of patients with IPF diagnosed radiologically or pathologically.

\section{MATERIAL AND METHOD}

The present investigation was a single-center and retrospective study. This study was approved by the university /local human research ethics committee and all procedures performed in studies involving human participants were in accordance with the ethical standards of the institutional and/or national research committee and with the 1964 Helsinki Declaration and its later amendments or comparable ethical standards. The study was carried out with the permission of University of Health Sciences Ankara Atatürk Chest Diseases and Thoracic Surgery Training and Research Hospital Ethics Committee (Permission granted: 12.07.2018/Decision no: 604).

We analyzed the records of 47 patients with IPF, diagnosed by radiologically or pathologically in the 8 th clinic of our hospital between January 2013 and December 2018. Age, sex, smoking history, pulmonary function test values, echocardiography (ECHO) results, life span, additional diseases, treatment information, laboratory results of patients were obtained from the hospital information system. We calculated the CAR as dividing the CRP level $(\mathrm{mg} / \mathrm{L})$ by the serum albumin level $(\mathrm{g} / \mathrm{L})$. In the GAP index and staging system, points are assigned to each variable (sex, age, FVC, DLCO) to obtain a total point score (GAP index) ranging from 0 to 8 (10). The GAP index is used to classify patients as at GAP stage I (0-3 points), GAP stage II ( $4-5$ points) or GAP stage III (6-8 points). In this study, the GAP index and stage were calculated for all patients in whom the relevant baseline assessments were available.

\section{Statistical Analysis}

Statistical analyses were carried out by using Statistical Package for the Social Sciences 22.0 soft ware version (SPSS Inc. Chicago, IL, USA). Descriptive statistics of the data were given as mean, standart deviation, median, lowest, highest, frequency and ratio values. The distribution of variables was measured by the Kolmogorov Simirnov Test. Independent Sample T Test, Kruskal-wallis and Mann-Whitney $U$ test were used for the analysis of quantitative independent data. The Chi-square Test was used for the analysis of qualitative independent data and the Fischer Test was used when the conditions of Chi-square Test weren't provided. The level of effect was investigated by univariate and multivariate logistic regression

\section{RESULTS}

A total of 47 patients with IPF were enrolled in this study. Forty four patients were male and 3 patients were female. The mean age of the patients was $66.4 \pm 7.7$ years. $12.8 \%$ of the patients were still smoking, $68.1 \%$ had quit smoking and $19.1 \%$ had never smoked. Mean smoking amount was $2.62 \pm 21.32$ pack-years. The most common respiratory symptom was dyspnea (68.1\%), followed by cough (57.4\%). Gastroesophageal reflux disease (40.4\%) was the most common additional disease with IPF. $42.6 \%$ of patients had respiratory failure. According to GAP index there were $25(53.2 \%)$ patients in stage I, $11(23.4 \%)$ patients in stage II, and 11 (23.4\%) patients in stage III. The baseline characteristics of the study population were presented in Table 1. 


\begin{tabular}{|c|c|c|c|}
\hline & & Min-Max & Mean \pm s.d./n-\% \\
\hline Age & & $50.0-87.0$ & $66.4 \pm 7.7$ \\
\hline \multirow{2}{*}{ Gender } & Female & & $3-6.4 \%$ \\
\hline & Male & & $44-93.6 \%$ \\
\hline \multirow{5}{*}{ Symptoms } & Fever & & $1-2.1 \%$ \\
\hline & Cough & & $27-57.4 \%$ \\
\hline & Dyspnea & & $32-68.1 \%$ \\
\hline & Tiredness & & $1-2.1 \%$ \\
\hline & Sputum & & $2-4.3 \%$ \\
\hline \multirow{2}{*}{ Additional diseases } & $(-)$ & & $19-40.4 \%$ \\
\hline & $(+)$ & & $28-59.6 \%$ \\
\hline \multirow{2}{*}{ Lung cancer } & $(-)$ & & $46-97.9 \%$ \\
\hline & $(+)$ & & $1-2.1 \%$ \\
\hline \multirow{2}{*}{ OSAS } & $(-)$ & & $37-78.7 \%$ \\
\hline & $(+)$ & & $10-21.3 \%$ \\
\hline \multirow{2}{*}{ GERD } & $(-)$ & & $28-59.6 \%$ \\
\hline & $(+)$ & & $19-40.4 \%$ \\
\hline \multirow{2}{*}{ Respiratory failure } & $(-)$ & & $27-57.4 \%$ \\
\hline & $(+)$ & & $20-42.6 \%$ \\
\hline \multirow{3}{*}{ Smoking status } & Nonsmoker & & $9-19.1 \%$ \\
\hline & Gave up & & $32-68.1 \%$ \\
\hline & Smoker & & $6-12.8 \%$ \\
\hline Smoking amounts (pack/year) & & $0.0-80.0$ & $29.62 \pm 21.32$ \\
\hline \multirow{4}{*}{ Desaturation } & No & & $5-10.6 \%$ \\
\hline & Mild & & $27-57.4 \%$ \\
\hline & Moderate & & $5-10.6 \%$ \\
\hline & Severe & & $10-21.3 \%$ \\
\hline \multirow{3}{*}{ GAP stage } & I & & $25-53.2 \%$ \\
\hline & II & & $11-23.4 \%$ \\
\hline & III & & $11-23.4 \%$ \\
\hline \multirow{2}{*}{ Status } & Alive & & $31-66.0 \%$ \\
\hline & Exitus & & $16-34.0 \%$ \\
\hline $\mathrm{EF}$ & & $35.0-65.0$ & $57.2 \pm 5.5$ \\
\hline PAP & & $19.0-70.0$ & $34.1 \pm 11.3$ \\
\hline 6MWT & & $75.0-550.0$ & $391.4 \pm 127.5$ \\
\hline DLCO & & $20.0-108.0$ & $59.0 \pm 19.5$ \\
\hline FEV1 & & $38.0-109.0$ & $74.3 \pm 19.0$ \\
\hline FVC & & $36.0-99.0$ & $68.4 \pm 16.9$ \\
\hline FEV1/FVC & & $70.0-112.0$ & $86.1 \pm 7.8$ \\
\hline Neutrophil & & $44.4-88.5$ & $63.9 \pm 10.1$ \\
\hline Lymphocyte & & $6.6-44.2$ & $25.0 \pm 8.0$ \\
\hline CRP & & $0.01-14.72$ & $2.34 \pm 3.50$ \\
\hline ALB & & $2.90-4.80$ & $3.99 \pm 0.48$ \\
\hline CRP/Albumin & & $0.00-4.60$ & $0.66 \pm 1.06$ \\
\hline $\mathrm{LDH}$ & & $3.9-1019.0$ & $270.6 \pm 161.6$ \\
\hline GAP index & & $1.00-8.00$ & $4.00 \pm 1.84$ \\
\hline
\end{tabular}

We divided the patients into 2 groups according to their life conditions. The rate of respiratory failure was significantly higher in the exitus group $(\mathrm{p}<0.05)$. In the exitus group GAP stage was significantly higher. The mean PAP value of exitus group was significantly higher than the alive groups $(\mathrm{p}<0.05)$. The mean 6-MWT was significantly lower in the exitus group $(\mathrm{p}<0.05)$. There were no significant differences according to the other parameters in both groups. They were shown in Table 2 and Table 3. 


\begin{tabular}{|c|c|c|c|c|}
\hline & & $\begin{array}{c}\text { Alive } \\
\text { Mean } \pm \text { s.d./n-\% }\end{array}$ & $\begin{array}{c}\text { Exitus } \\
\text { Mean } \pm \text { s.d./n-\% }\end{array}$ & $\mathbf{p}$ \\
\hline \multicolumn{2}{|l|}{ Age } & $66.2 \pm 7.4$ & $66.9 \pm 8.5$ & $0.747^{t}$ \\
\hline \multirow{2}{*}{ Gender } & Female & $3-9.7 \%$ & $0-0.0 \%$ & \multirow{2}{*}{$0.541^{x}$} \\
\hline & Male & $28-90.3 \%$ & $16-100.0 \%$ & \\
\hline \multirow{5}{*}{ Symptoms } & Fever & $1-3.2 \%$ & $0-0.0 \%$ & $1.000^{\mathrm{X}^{2}}$ \\
\hline & Cough & $18-58.1 \%$ & $9-56.3 \%$ & $0.905^{\mathrm{X}^{2}}$ \\
\hline & Dsypnea & $22-71.0 \%$ & $2-12.5 \%$ & $0.969 \mathrm{x}^{2}$ \\
\hline & Tiredness & $0-0.0 \%$ & $1-6.3 \%$ & $0.340^{\mathrm{X}^{2}}$ \\
\hline & Sputum & $0-0.0 \%$ & $2-12.5 \%$ & $0.111^{\mathrm{x}^{2}}$ \\
\hline \multirow{2}{*}{ Additional diseases } & $(-)$ & $15-48.4 \%$ & $4-25.0 \%$ & \multirow{2}{*}{$0.122^{x}$} \\
\hline & $(+)$ & $16-51.6 \%$ & $12-75.0 \%$ & \\
\hline \multirow{2}{*}{ Lung cancer } & $(-)$ & $31-100 \%$ & $15-93.8 \%$ & \multirow{2}{*}{$0.340^{\mathrm{x}}$} \\
\hline & $(+)$ & $0-0.0 \%$ & $1-6.3 \%$ & \\
\hline \multirow{2}{*}{ OSAS } & $(-)$ & $24-77.4 \%$ & $13-81.3 \%$ & \multirow{2}{*}{$0.761^{\mathrm{X}^{2}}$} \\
\hline & $(+)$ & $7-22.6 \%$ & $3-18.8 \%$ & \\
\hline \multirow{2}{*}{ GERD } & $(-)$ & $19-61.3 \%$ & $9-56.3 \%$ & \multirow{2}{*}{$0.739^{x}$} \\
\hline & $(+)$ & $12-38.7 \%$ & $7-43.8 \%$ & \\
\hline \multirow{2}{*}{ Respiratory failure } & $(-)$ & $23-74.2 \%$ & $4-25.0 \%$ & \multirow{2}{*}{$0.001^{\mathrm{x}}$} \\
\hline & $(+)$ & $8-25.8 \%$ & $12-75.0 \%$ & \\
\hline \multirow{3}{*}{ Smoking status } & Nonsmoker & $7-22.6 \%$ & $2-12.5 \%$ & \multirow{3}{*}{$0.694^{x}$} \\
\hline & Gave-up & $20-64.5 \%$ & $12-75.0 \%$ & \\
\hline & Smoker & $4-12.9 \%$ & $2-12.5 \%$ & \\
\hline \multicolumn{2}{|c|}{ Smoking mounts (pack/year) } & $27.1 \pm 22.2$ & $34.6 \pm 19.1$ & $0.318^{\mathrm{m}}$ \\
\hline \multirow{4}{*}{ Desaturation } & No & $4-12.9 \%$ & $1-6.3 \%$ & \multirow{4}{*}{$0.211^{\mathrm{x}^{2}}$} \\
\hline & Mid & $19-61.3 \%$ & $8-50.0 \%$ & \\
\hline & Moderate & $2-6.5 \%$ & $3-18.8 \%$ & \\
\hline & Severe & $6-19.4 \%$ & $4-25.0 \%$ & \\
\hline \multirow{3}{*}{ GAP Stage } & I & $20-64.5 \%$ & $5-31.3 \%$ & \multirow{3}{*}{$0.008^{\mathrm{x}}$} \\
\hline & II & $3-9.7 \%$ & $8-50.0 \%$ & \\
\hline & III & $8-25.8 \%$ & $3-18.8 \%$ & \\
\hline \multicolumn{5}{|c|}{$\begin{array}{l}\mathrm{t} \mathrm{t} \text { test / m Mann-whitney u test / } \mathrm{x}^{2} \text { Ki-kare test (Fischer test) } \\
\text { Data are presented as n. median [interquartile]. } \mathrm{n}[\%] \text {. or mean } \pm \mathrm{SD} \text {. } \\
\text { OSAS: Obstructif Sleep Apne Syndrome } \\
\text { GERD: Gastroesophageal Reflux Disease } \\
\text { GAP: Gender-Age-Physiology }\end{array}$} \\
\hline
\end{tabular}

\begin{tabular}{|c|c|c|c|}
\hline & Alive & Exitus & \multirow[b]{2}{*}{$\mathrm{p}$} \\
\hline & Mean \pm s.d. & Mean \pm s.d. & \\
\hline $\mathrm{EF}$ & $58.0 \pm 4.7$ & $55.6 \pm 6.8$ & $0.232^{\mathrm{m}}$ \\
\hline PAP & $30.9 \pm 10.3$ & $40.3 \pm 11.0$ & $0.002^{\mathrm{m}}$ \\
\hline 6MWT & $428.6 \pm 101.1$ & $319.5 \pm 145.3$ & $0.006^{\mathrm{t}}$ \\
\hline DLCO & $59.9 \pm 21.2$ & $56.4 \pm 13.8$ & $0.656^{\mathrm{t}}$ \\
\hline DLCO/VA & $86.1 \pm 26.6$ & $83.1 \pm 17.9$ & $0.755^{\mathrm{t}}$ \\
\hline FEV1 & $77.9 \pm 18.6$ & $67.3 \pm 18.4$ & $0.069^{t}$ \\
\hline FVC & $71.6 \pm 16.5$ & $62.3 \pm 16.7$ & $0.073^{t}$ \\
\hline FEV1/FVC & $85.4 \pm 5.9$ & $87.6 \pm 10.7$ & $0.372^{\mathrm{m}}$ \\
\hline Neutrophil & $62.7 \pm 9.9$ & $66.2 \pm 10.6$ & $0.238^{\mathrm{m}}$ \\
\hline Lymphocyte & $26.4 \pm 8.0$ & $22.3 \pm 7.4$ & $0.051^{\mathrm{m}}$ \\
\hline CRP & $2.66 \pm 4.07$ & $1.71 \pm 1.94$ & $0.719^{\mathrm{m}}$ \\
\hline ALB & $4.03 \pm 0.43$ & $3.92 \pm 0.57$ & $0.464^{\mathrm{m}}$ \\
\hline CRP/Albumin & $0.75 \pm 1.24$ & $0.48 \pm 0.55$ & $0.621^{\mathrm{m}}$ \\
\hline LDH & $277.4 \pm 193.3$ & $257.3 \pm 71.4$ & $0.653^{\mathrm{m}}$ \\
\hline GAP Index & $3.74 \pm 1.69$ & $4.50 \pm 2.07$ & $0.222^{\mathrm{m}}$ \\
\hline \multicolumn{4}{|c|}{$\begin{array}{l}\mathrm{t} t \text { test / } \mathrm{m} \text { Mann-whitney u test } \\
\text { Data are presented as n. median [interquartile]. } \mathrm{n} \text { [\%]. or mean } \pm \text { SD.. EF:Ejection } \\
\text { Fraction . PAP: Pulmonary arteriel pressure } \\
\text { 6- (MWT): 6-minute walk test. DLCO: Diffusing capacity of the lungs for carbon } \\
\text { monoxide. FEV1: Forced Expiratory Volume in 1. } \\
\text { FVC: Forced vital capacity. CRP:C reactive protein. LDH: Laktate Dehidrogenase. } \\
\text { GAP: Gender-Age-Physiology }\end{array}$} \\
\hline
\end{tabular}

The Assesment of PAP, 6MWT, GAP index and CRP/ Albumin ratio according to life condition was shown in Figure.

In logistic regression analysis the significant predictive effect of PAP, 6 min walking test result, respiratory failure and GAP stage were observed in predicting mortality $(\mathrm{p}<0.05)$ It was shown in Table 4.

There was no significant difference between the CRP/ albumin values of the patients in each of the 3 the GAP stages $(\mathrm{p}<0.05)$. It was shown in Table 5.

\section{Table 4. Factors affecting mortality in IPF}

\begin{tabular}{|lccc|}
\hline & OR & \%95 confidence interval & $\mathbf{p}$ \\
\hline PAP & 1.09 & $1 \cdot 02-1 \cdot 16$ & 0.015 \\
6 Min Walk Test & 0.99 & $0.99-1 \cdot 00$ & 0.013 \\
Respiratory failure & 8.62 & $2 \cdot 15-34 \cdot 57$ & 0.002 \\
GAP Stage & 4.00 & $1 \cdot 10-14.50$ & 0.035 \\
\hline Logistic Regression & & & \\
\hline
\end{tabular}


Table 5. The evaluation of CRP/Albumin ratio according to GAP stage

\begin{tabular}{|lcccc|}
\hline & GAP Stage 1 & GAP Stage 2 & GAP Stage 3 & \multirow{2}{*}{ p } \\
\cline { 2 - 4 } & Mean \pm s.d. & Mean \pm s.d. & Mean \pm s.d. & \\
\hline CRP/Albumin & $0.71 \pm 1.03$ & $0.50 \pm 0.88$ & $0.70 \pm 1.33$ & $0,709^{\mathrm{K}}$ \\
\hline${ }^{\mathrm{K} \text { Kruskal-wallis (Mann-whitney u test) }}$ & & & \\
\hline
\end{tabular}

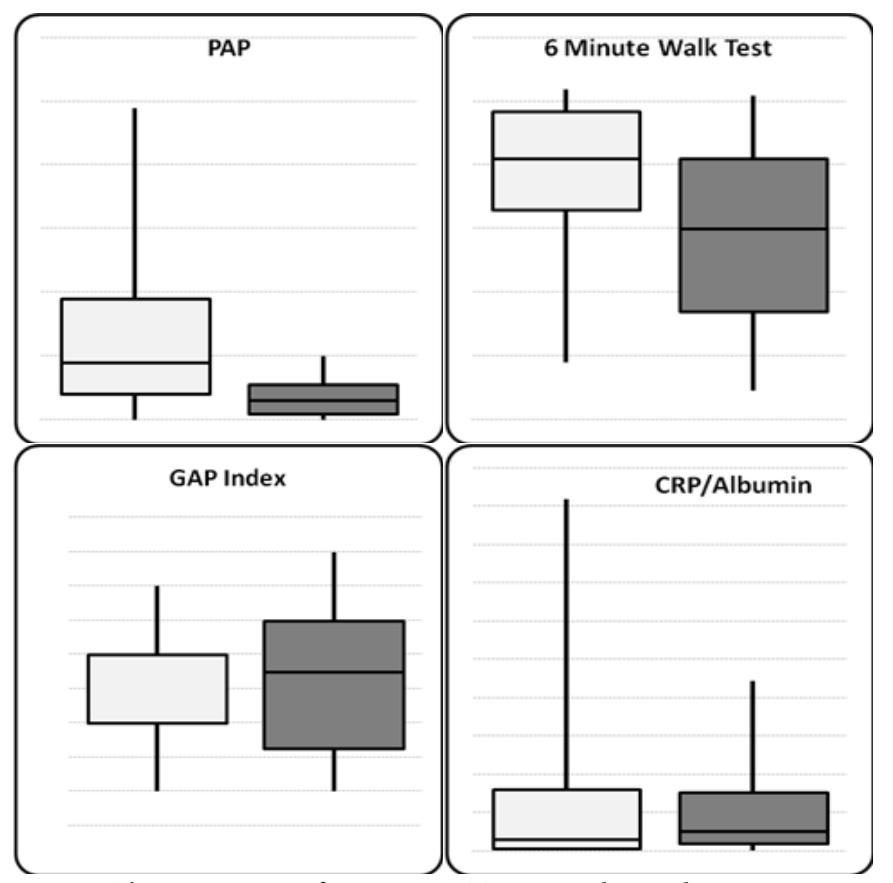

Figure. The assesment of PAP, 6MWT, GAP index and CRP/ Albumin ratio according to life condition

\section{DISCUSSION}

Morbidity and mortality are high in IPF and the clinical course and prognosis vary widely among individual patients (18). Many clinical, radiographic, physiologic, and pathologic predictors are associated with increased or decreased survival in IPF. Lower baseline FVC and DLCO, as well as declining FVC or DLCO during 6 or 12 months of follow-up, are predictive of worse survival (19). In this retrospective study we compared the GAP index and CAR in order to evaluate the prognosis, clinical course and survival of patients with IPF. They are both easy tests but have limited capability to provide accurate prognoses for IPF patients. Lee et al. (20) compared the predictive values of Composite Physiologic Index (CPI) and gender-age-physiology (GAP) models in 832 patients and they found that they are significantly useful predictors for IPF and similarly Song et al. (21) found that advanced GAP stage was the only predictor of treatmentrelated acute exacerbation of IPF. They suggested physicians to be consider GAP stage, which reflects the severity of IPF, during treatment of small cell lung cancer with IPF. Contrary to some reports $(22,23)$, Song et al. (24) and Olson and coworkers' (25) determined that age and sex were not independent predictors of survival in multivariate analyses. Our findings were similar. We evaluated the patients according to their life conditions in our study and it was observed that the GAP stage had a predictive effect on mortality in patients with IPF so our findings seem to agree with those of Lee et al. (20).

The CAR, first proposed by Fairclough et al. (26) has been applied as a prognostic marker in many cancer types and as an independent risk factor for mortality in sepsis. There are no previous studies have investigated using CAR to predict the prognosis of IPF. We have investigated the association between the ratio of CAR and the clinical outcome of patients with IPF but we haven't found any relation and the CAR of the patients were similar in all three GAP stage. Thus we think that it is not meaningful to use as a prognostic factor in IPF according to our results.

Six-MWT, desaturation, hospitalization due to respiratory problem, pulmonary hypertension (PAH), acute exacerbation or lung cancer should be considered for a more absolute prediction of prognosis in IPF. The presence of comorbidities with IPF can significantly influence the prognosis. Song et al. (24) and Cai et al. (27) showed in their studies that PAH was associated with a poor outcome. Distance walked in 6 min was independently related to mortality by multivariate analysis in Caminati and coworkers' study (28). According to the our results High PAP value, low 6 MWT results and respiratory failure were considered as predictors of mortality in patients with IPF.

\section{CONCLUSION}

Gender, age, and physiology stage is easy and useful to predict the prognosis of IPF. The elevation of PAP, low $6 \mathrm{MWT}$ and presence of respiratory failure are poor prognostic factors in IPF. As well as CAR is used as a prognostic factor in many diseases it isn't found to be valueable for predicting the prognosis of IPF in our study. 


\section{ETHICAL DECLARATIONS}

Ethics Committee Approval: The study was carried out with the permission of University of Health Sciences Ankara Atatürk Chest Diseases and Thoracic Surgery Training and Research Hospital Ethics Committee (Permission granted: 12.07.2018 /Decision no: 604).

Informed Consent: Because the study was designed retrospectively, no written informed consent form was obtained from patients.

Referee Evaluation Process: Externally peer-reviewed.

Conflict of Interest Statement: The authors have no conflicts of interest to declare.

Financial Disclosure: The authors declared that this study has received no financial support.

Author Contributions: All of the authors declare that they have all participated in the design, execution, and analysis of the paper, and that they have approved the final version.

\section{REFERENCES}

1. Raghu G, Collard HR, Egan JJ, et al. An official ATS/ERS/JRS/ ALAT statement: idiopathic pulmonary fibrosis: evidence-based guidelines for diagnosis and management. Am J Respir Crit Care Med 2011; 183: 788-824.

2. Jo HE, Glaspole I, Grainge C, et al. Baseline characteristics of idiopathic pulmonary fibrosis: analysis from the Australian idiopathic pulmonary fibrosis registry. Eur Respir J 2017; 49: pii: 1601592

3. Hutchinson J. Idiopathic pulmonary fibrosis: another step in understanding the burden of this disease. Eur Respir J 2016; 48: 26-28.

4. Marshall DC, Salciccioli JD, Shea BS, Akuthota P. Trends in mortality from idiopathic pulmonary fibrosis in the European Union: an observational study of the WHO mortality database from 2001-2013. Eur Respir J 2018; 51: pii: 1701603.

5. Navaratnam V, Fleming KM, West J, et al. The rising incidence of idiopathic pulmonary fibrosis in the U.K. Thorax 2011; 66: 462-67.

6. Algranti E, Saito CA, Silva D, Carneiro APS, Bussacos MA. Mortality from idiopathic pulmonary fibrosis: a temporal trend analysis in Brazil, 1979-2014. J Bras Pneumol 2017; 43: 445-50.

7. Ley B, Ryerson CJ, Vittinghoff E, et al. A multidimensional index and staging system for idiopathic pulmonary fibrosis. Ann Intern Med 2012; 156: 684-95.

8. Meyer KC. New treatments for idiopathic pulmonary fibrosis. Clinical Pulmonary Medicine. 2016; 23: 241-51.

9. Liu Z, Jin K, Guo M, et al. Prognostic value of the CRP/Alb ratio, a novel inflammation-based score in pancreatic cancer. Ann Surg Oncol 2017; 24: 561-68.

10.Zhang Y, Zhou GQ, Liu X, et al. Exploration and validation of C-reactive protein/albumin ratio as a novel inflammation-based prognostic marker in nasopharyngeal carcinoma. J Cancer 2016; 7: 1406-12.
11. Shibutani M, Maeda K, Nagahara H, et al. Prognostic significance of the preoperative ratio of $\mathrm{C}$-reactive protein to albumin in patients with colorectal cancer. Anticancer Res 2016; 36: 9951001.

12.Xu XL, Yu HQ, Hu W, Song Q, Mao WM. A novel inflammationbased prognostic score, the C-reactive protein/albumin ratio predicts the prognosis of patients with operable esophageal squamous cell carcinoma. PLoS One 2015; 10: e0138657.

13.Zhang F, Ying L, Jin J, et al. The C-reactive protein/albumin ratio predicts long-term outcomes of patients with operable non-small cell lung cancer. Oncotarget 2017; 8: 8835-42.

14. Miyazaki T, Yamasaki N, Tsuchiya T, et al. Ratio of C-reactive protein to albumin is a prognostic factor for operable non-smallcell lung cancer in elderly patients. Surg Today 2016; 47: 836-43.

15.Zhou T, Zhan J, Hong S, et al. Ratio of C-reactive protein/albumin is an inflammatory prognostic score for predicting overall survival of patients with small-cell lung cancer. Sci Rep 2015; 5: 10481.

16. Young W. Koh, Hyun W. Prognostic impact of C-reactive protein/ albumin ratio on the overall survival of patients with advanced nonsmall cell lung cancers receiving palliative chemotherapy. Lee Medicine (Baltimore) 2017; 96: e6848.

17. Sun P, Chen C, Xia Y, et al. The ratio of c-reactive protein/albumin is a novel inflammatory predictor of overall survival in cisplatinbased treated patients with metastatic nasopharyngeal carcinoma. Dis Markers 2017; 2017: 6570808.

18. Ley B, Collard HR, King TE Jr. Clinical course and prediction of survival in idiopathic pulmonary fibrosis. Am J Respir Crit Care Med. 2011; 183: 431-40.

19. Salisbury ML, Xia M, Zhou Y, et al. Idiopathic pulmonary fibrosis: gender-age-physiology index stage for predicting future lung function decline. Chest 2016; 149: 491-98.

20.Lee SH, Park JS, Kim SY, et al. Comparison of CPI and GAP models in patients with idiopathic pulmonary fibrosis: a nationwide cohort study. Sci Rep 2018; 8: 4784.

21. Song MJ, Lim SY, Park JS, et al. Prognosis of small cell lung cancer with 1diopathic pulmonary fibrosis: assessment according to GAP stage. J Oncol 2019; 2019: 5437390

22.Kim HJ, Perlman D, Tomic R. Natural history of idiopathic pulmonary fibrosis. Respir Med 2015; 109: 661-70.

23. Beydon N, Davis SD, Lombardi E, et al. American Thoracic Society/European Respiratory Society Working Group on infant and young children pulmonary function testing. an official American Thoracic Society/European Respiratory Society statement: pulmonary function testing in preschool children. Am J Respir Crit Care Med 2007; 175: 1304-45.

24. Song H, Sun D, Ban C, et al. Independent clinical factors relevant to prognosis of patients with idiopathic pulmonary fibrosis. Med Sci Monit 2019; 25: 4193-201.

25. Olson AL, Swigris JJ, Lezotte DC, et al. Mortality from pulmonary fibrosis increased in the United States from 1992 to 2003. Am J Respir Crit Care Med 2007; 176: 277-84.

26. Fairclough E., Cairns E., Hamilton J. \& Kelly C. Evaluation of a modified early warning system for acute medical admissions and comparison with $\mathrm{C}$-reactive protein/albumin ratio as a predictor of patient outcome. Clin. Med. 9,2009; 30-33.

27. Cai M, Zhu M, Ban C, et al. Clinical features and outcomes of 210 patients with idiopathic pulmonary fibrosis. Chin Med J (Engl) 2014; 127: 1868-73 
28. Caminati A, Bianchi A, Cassandro R, Mirenda MR, Harari S.

Walking distance on 6-MWT is a prognostic factor in idiopathic pulmonary fibrosis. Respir Med 2009; 103: 117-23. 